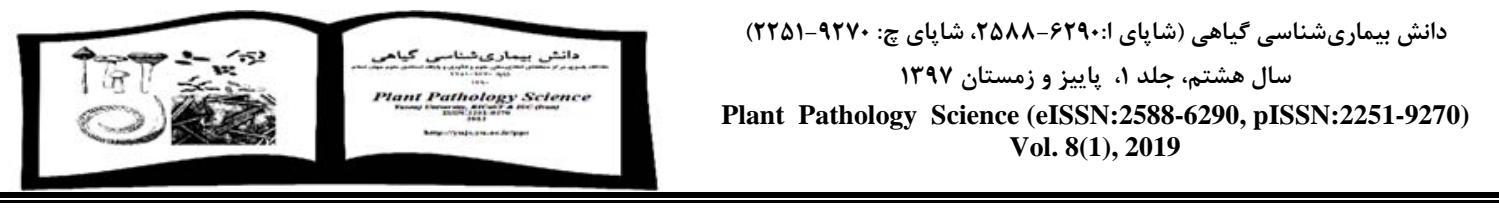

\title{
Important Characters in Identification of Cladosporium spp.
}

\section{AMIRREZA AMIRMIJANI}

Department of Plant Protection, University of Jiroft, Jiroft, Iran

( $\triangle$ : ar.amirmijani@ujiroft.ac.ir)

Received: 25.10 .2018

Accepted: 27.01.2019

Amirmijani, A. M. 2019. Important characters in identification of Cladosporium spp.

Plant Pathology Science 8(1):50-59. DOI: 10.2982/PPS.8.1.50.

Abstract: The genus Cladosporium is one of the largest genera of fungi. Its species live in different ways: as plant pathogens, as saprobes in the soil or on decaying plant materials, or as hyperparasitic on other fungi. Morphological characteristics of conidia such as shape, formation and surface ornamentation, the features of conidiophores including shape, ramification and conidiogenous loci, and sequencing data from different regions of DNA are very important for identification of Cladosporium species. In this article the important morphological characteristics and genomic regions which are useful for identification of closely related or cryptic species of this genus, are illustrated.

Key words: Ramoconidium, Intercalary conidia, Cryptic species,

\section{صفات مهم در تشخيص كونههاى Cladosporium}

$$
\begin{aligned}
& \text { امير رضا امير ميجانى } \\
& \text { كروه گياهيزشكى، دانشعاه جيرفت }
\end{aligned}
$$

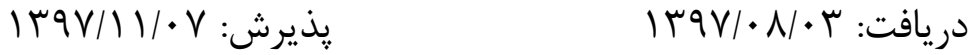

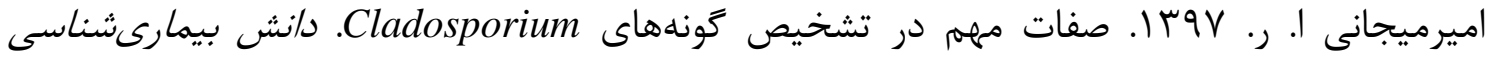

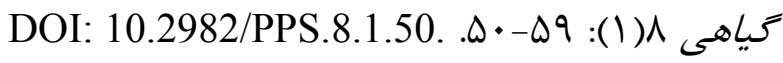

$$
\begin{aligned}
& \text { جكيده: Cladosporium يكى از جنسهاى بزرگ قارجها است كه گونههاى آن اغلب به صورت } \\
& \text { بيماركر گياهان، گَندرو در خاك و يا روى مواد گياهى خشك، يا فراانكل ساير قارجها زندكى مى كنند. }
\end{aligned}
$$

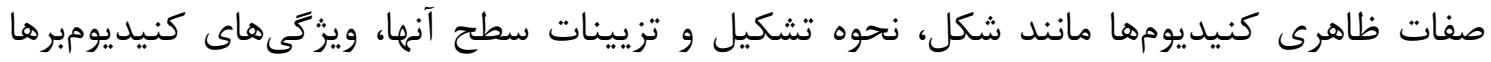

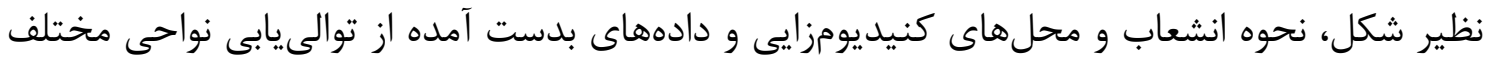

$$
\begin{aligned}
& \text { DNA }
\end{aligned}
$$

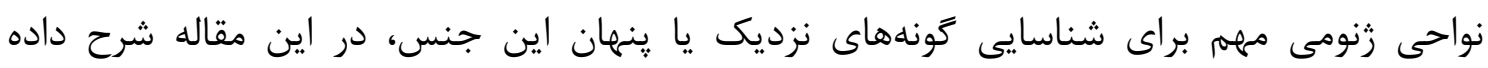

$$
\begin{aligned}
& \text { شدهاند. } \\
& \text { وازههاى كليدى: راموكنيديوم، كنيديومهاى ميانى، كونه ينهان }
\end{aligned}
$$


يكى از بزرَترين جنسهاى ناهمگن قارجها است كه تقريباً از تمامى نقاط دنيا كزارش شده و در بر گيرنده بالغ بر •VV نام است (David 1997). اين جنس داراى كونههاى بيمارگر انسان و گياه، انگل قارجها، گَندرو و درونزى(Endophyte) است كه به روشهاى مختلف زندگى روزمره انسآنها را تحت تاثير قرار مىدهند (Crous et al. 2007). هاگهاى Cladosporium) بخشى از هاتهاى موجود در هوا را تشكيل مىدهند و از عوامل آلودگى و فساد محصولات غذايى و يا صنعتى و لكَه بركى در گیاهان به شمار مىروند. گونههاى گَندرو اين جنس مانند C. cladosporioides (Fresen.) G.A. de Vries و C. herbarum (Pers.: Fr.) Link روى ساقه و بركهاى مرده يا يرمرده گياهان علفى و جوبى رشد كرده و به عنوان عوامل آلوده كننده ثانويه روى زخمهاى نكروزه بركها كه توسط ساير قارجها ايجاد شده است، عمل مى كنند. همجنين كونه .C. sphaerosporium s.1 از عوامل بالقوه مرتبط با يزشكى بوده و سبب بروز آلرزى و ناراحتىهاى ريوى مىشود (Hoog et al. 2000). علاوه بر اين برخى گونههاى آن بيماركر گياهان بوده و سبب بروز لكه بركى در آنها مىشوند و گونه .C. aphidis Thüm. قادر به آلوده كردن آفات مهرم كياهى خصوصاً شتهها و سفيد بالك بوده و از جنبه كنترل بيولوزيك حايز اهميت است

.(Abdel-Baky and Abdel-Salam 2003)

ا- تاريخجه آرايلبندى Cladosporium

آرايهبندى Cladosporium براى اولين بار توسط يرسون و با توصيف كونهاى از آن تحت عنوان Dematium herbarm Pers. "Cladosporium" به عنوان يك جنس، توسط لينك (Link 1816) مرسوم شد و بدنبال آن دو گونه Heuchert et al. ( Cladosporium قرار داده شدند D. abietinum Pers. و D. Derbarum 2005). بر اساس يزوهش ديويد (David 1997) دو عامل مهمم شامل تعريف وسيع حد و مرز اين جنس و در نظر گرفتن ارتباط آن با ميزبآنهاى مختلف در افزايش سريع نامهاى مرتبط با جنس Cladosporium دخيل بوده است. به همين منظور يزوهشى اوليه توسط ديويد (David 1997) براى تعيين حدود و ثغور جنس Cladosporium صورت گرفت. طبق نوشته وى همه گونهاى Cladosporium s. str. محل جدا شدن كنيديوم از زنجيره و سلول كنيديومزا، از ساير جنسهاى نزديك جدا مىشوند. ايشان با بررسى گونههاى دو جنس Cladosporium و 
ميكروسكوٍ الكترونى SEM تعريف جديدى از Cladosporium ارايه كرد. بر اين اساس تمام كونهاى Cladosporium با مفهوم خاص، با دارا بودن كنيديومهايى با هيلوم برآمده و تاجى شكل و با مركز حنبدى شكل (Coronate) مشخص در محل كنيديومزايى (Scar) از ساير كونههاى جنسهاى نزديك، تفكيك مىشوند. اين جنس در آرايهبندى نوين قارجها در تيره Cladosporiaceae، راسته Capnodiales، رده Dothideomycetes

\section{Cladosporium ب- ريختشناسى Fونdهاى}

״ركَنه اين قارجها روى ميزبان زراكنده تا مجتمع است. اغلب به رنت سبز زيتونى متمايل به قهوهاى تا قهوهاى تيره ديده مىشود. ميسليوم داخلى و فرورفته و داراى ريسههاى هوايى است. ريسهها منشعب، داراى بند، سطح آنها صاف تا گاهى زبر يا زگيلى است. اغلب فاقد استروما يا در

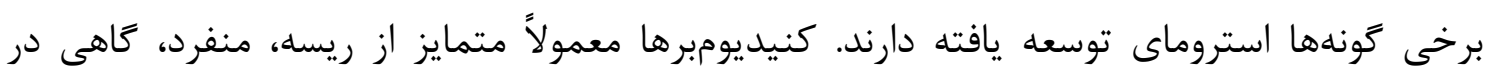
دستههايى با تراكم كم تا متراكم، معمولاً ايستاده تا خوابيده، صاف تا خميده و به صورت انتهايى يا جانبى روى ريسه تشكيل مىشوند، معمولاً بدون انشعاب يا داراى انشعابهاى كوتاه دندانه مانند تا بلند

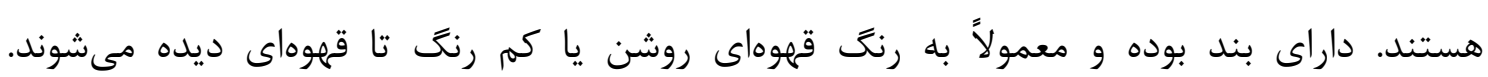
كنيديومزايى آنها از نوع هولوبلاستيك، رشد آنها اغلب سيميوديال و به ندرت مونويوديال است. سلول كنيديومزا ادغام شده، انتهايى يا ميانى روى كنيديومبر تشكيل مىشود. محلهاى كنيديومزايى كاهى به صورت ضخيم و تيره ديده مىشوند. كنيديومها فراوان اغلب در زنجيرههاى آكرويتال منشعب يا غير منشعب و خيلى كم به صورت انفرادى روى كنيديومبر تشكيل مىشوند، از نظر شكل بسيار متنوع هستند. شكل آنها اغلب نيمهكروى، كروى، تخممرغى، واز تخممرغى، بيضوى، دوكى، ليمويى، نيمه استوانهاى تا استوانهاى بوده و بدون بند يا داراى جندين بند عرضى هستند. معمولاً داراى رنحدانه، سطح آنها صاف، زَيلى خفيف تا زكيلى مشخص يا خار مانند، با هيلوم برجسته و تاجى شكل است. كنيديومزايى ميكروسيكليك در اغلب كونهها وجود دارد (Bensch et al. 2012). خصوصيات كنيديومبر مانند عرض، انشعابها و محل كنيديومزايى، ابعاد، شكل و انواع كنيديوم و تزيينات سطح آنها، در تشخيص كونههاى Cladosporium، اهميت زيادى دارند (Amirmijani et al. 2013, Khodaparast et al. 2012). ساير خصوصيات نظير عرض ريسه، توليد ساختارهاى كلاميدوسيورمانند روى ريسه، وجود يا عدم وجود استروما و كنيديومزايى كوتاه جرخه از ارزش كمترى برخوردار هستند. (Microcyclic conidiation) 
كنيديومبر در گونههاى اين جنس اغلب ايستاده، استوانهاى يا نخى شكل است و كاهى به دليـل رشــ سيميوديال، به صورت خميده و زانويى ديده مىشود، اين كنيديومبرها كاهى داراى تورمهاى يكطرفـهـ C. macrocarpum و C. herbarum مانند آنجه در كونسههـاى (Torulose) و دو طرفه (Nodulose) ديده مىشود (Amirmijani et al. 2015a) و يا بدون تورم مانند افراد متعلق به كَنـه مركـب C. cladosporioides هستند (Amirmijani et al. 2014). در اغلب كونهها كنيديومبرهـا معمـولاً بــهـ صورت انفرادى در قسمتهاى جانبى يا انتهايى ريسه و در تعداد اندكى بصـورت دسـتهــاى مجتمـع درون استروماهاى كوجى تا توسعه يافته (مانند گونـه C. neriicola شـكل 2D تشـكيل مسىشـوند. برخى گَونهها داراى دو نوع كنيديومبر (متفاوت در صفات ظاهرى مانند طول، عرض، تعداد بند، رنگ و ضخامت ديواره) بوده و به نوعى دوشكلى دارند. علاوه بر صفات كفته شده وجود يا عدم وجود انشـعاب

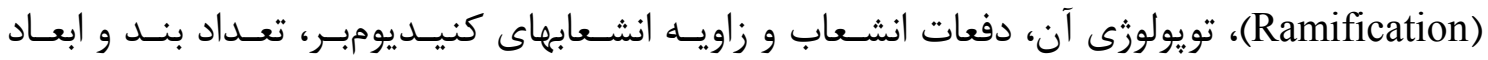
كنيديومبر (طول و عرض)، به طور خاص عرض آن، به تشخيص كمـك مسى كنــــ. روى كنيـديومبـر، سلول كنيديومزا عموماً به صورت انتهايى و كاهى ميانى و به صورت ادغـام شـده ايجـاد مسىشـوند. در

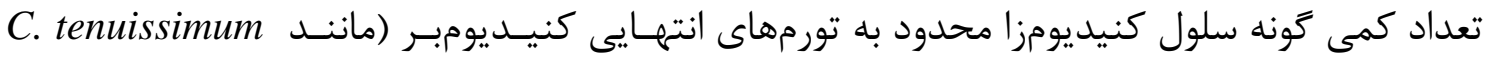
Cooke) و يا تورمهـاى ميـانى آن (ماننـد C. herbarum و C. oxporum Berk. \& M.A. Curtis) است كه اين صفتى مناسب بـراى تشـخيص كونسه اسـت (Amirmijani et al. 2014, 2015a). تعـداد محلهاى كنيديومزايى، زخم (Scar) ناشى از آن و عرض آن نيز به تشخيص كونههـا كمـك مسى كنــ (1A (شكل)

\section{r-r- انواع كنيديومها}

گونهاى Cladosporium قابليت توليـد كنيـديوم در زنجيـرههـاى حقيقى آكرويتـال (Acropetal) منشعب را دارند و تشكيل كنيديوم در زنجيره يا به صورت انفرادى صفتى كليـدى در تشـخيص اسـت (Bensch et al. 2012). در زنجيره كنيديوم اين قارج جندين نـوع كنيـديوم تشـكيل مسىشـود. ايسن زنجيره كنيديومى از قاعده به سـمت نـوك مشـتمل بــر راموكنيـديوم حقيقىى، راموكنيـديوم ثانويـه، كنيديومهاى ميانى (Intercalary conidia) و كنيديومهاى كوجى انتهايى است. اصطلاح راموكنيديوم براى كنيديومهايى كه در قاعده زنجيره كنيديومى قرار داشته و در نـوك بـيش از (Ramoconidium) يكى محل كنيديومزايى دارند توسط اليس (Ellis 1971) استفاده شده اسـت، امـا بـه اعتقــاد شـوبرت Slightly جنانجه راموكنيديوم داراى قاعده تخت (Truncate) يا انـدكى محـد (Schubert 2005) convex)، بدون ضخيم شدهى و فاقد ساختار گنبدى شكل در مركز با ديوارههاى برآمده باشد، به 


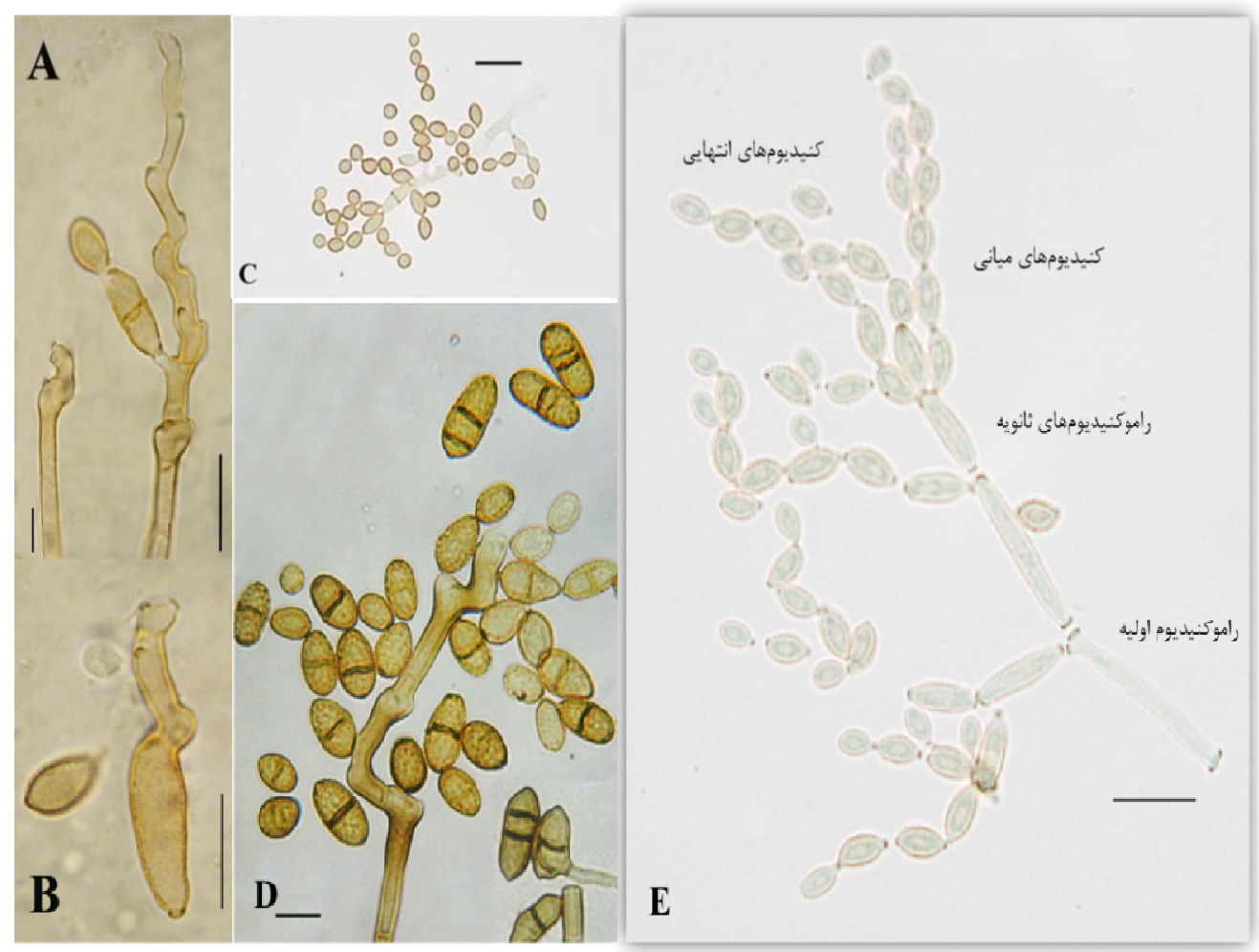

شكل ا- كنيديوم در گونههاى Cladosporium: سلول كنيديوم زا با هيلوم و زخم برجسته در

Fونه Cladosporium herbarum، Cladosporium كنيديوم انتهايى كروى با سطح صاف در كونه Dalotolerans

كونه Cladosporium cladosporioides s.s.

Figure 1. Conidia of Cladosporium. A-B: Conidiogenous cell with hilum and scar in Cladosporium herbarum, C: terminal conidia with smooth surface in Cladosporium halotolerans, D: Surface ornamentation of conidia in Cladosporium macrocarpum, E: Different conidia in Cladosporium cladosporioides s.s.

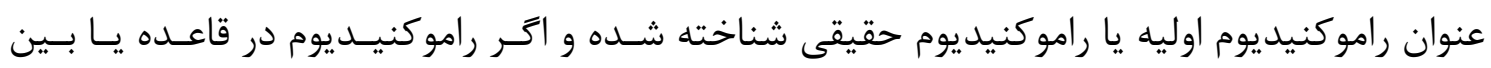
زنجيره كنيديومى واقع شده و در قاعده خود محدب و با ديواره ضخيم و زخم مشخص باشد، به عنوان راموكنيديوم ثانويه (Secondary ramoconidium) در نظر كرفته مىشود. وجـود راموكنيـديوم اوليـهـ يكى ويزگى با ارزش محدود براى تشخيص گونههاى Cladosporium است، جرا كه ايسن كنيـديوم بــه ندرت تشكيل مىشود. در صورت تشكيل شدن، ابعاد و تعداد بندهاى ميانى آن به تشخيص گَونههـاى خاص كمك مى كند. طول كنيديوم و تعداد بندهاى ميانى آن، بسيار متغير بـوده و بــه تنهـايى صـفت مناسبى براى تشخيص نيست و در كنار ساير صفات به تشخيص كمك مسى كنــد امـا عـرض كنيـديوم براى تعيين حدود گونهها نسبتاً مناسبتر است. كنيديومهاى انتهايى معمولاً در نوى كاملاً گرد بوده و 
فاقد هر گونه اسكار يا هيلـوم در نـوكى و فاقـد بنــد هسـتند شـكل كنيـديومهاى انتهـايى در تفكيـك

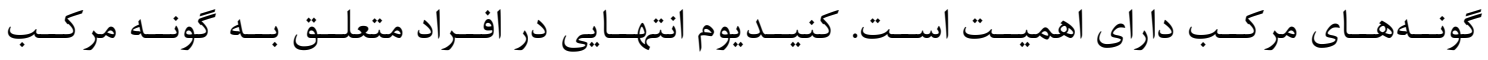

C. sphaerosporium Penz. بهصورت كشيده و با سطح صاف و در گونه مر كب. cladosporioides به صورت كروى تا (به ندرت نيمه كروى) ديده مسىشـوند. برجسـتخى نـوك كنيـديوم و زخـم محـل كنيديوم زايى از صفات مهم در تشخيص اين جنس و گونههاى آن هستند، عرض هيلوم، تعداد زخم و محل تشكيل آنها در تفكيك كونههـاى نزديـك مـوثر هسـتند. حـد فاصـل كنيـديومهـاى انتهـايى و راموكنيديوم ثانويه، كنيديومهاى ميانى قرار دارند (شكل r). تزئينـات سـطح كنيـديوم در كونـهـهـاى مختلف متفاوت است و به صورت صاف، زخيلى خفيف تـا زخيلس (C. herbarum species complex) يا خاردار ديده مىشود (شكل ()).

\section{PNA r-r - توالىيابى نواحى مختلف}

امروزه استفاده از توالىيابى DNA كمك زيادى به آرايهبندى قارجها كرده است. استفاده از زنهاى كد كننده RNA ريبوزومى، به دليل دارا بودن نسخههاى فراوان در زنوم و تكامل همزمان آنها، بسيار مورد توجه بوده است. زير واحدهاى اين زنها از سرعت تكامل متفاوتى برخوردار بوده و اطلاعات حاصل، آنها را تبديل به ابزارهاى مفيد براى آرايلبندى كرده است، به طورى كه ناحيه ITS-rDNA قرار زرفته است. هر جند در اكثر موارد استفاده تنها از اين ناحيه زنومى قادر به تفكيك گونهها نبوده است و استفاده همزمان از ويزگى هاى ريختشناسى و توالىيابى قسمتهايى از ديكر نواحى زنومى مانند عامل بسط دهنده ترجمه (tef1)، زن اكتين (act) و زن توبولين (tub) ضرورى است. بر اساس نوشته بنش و همكاران (Bensch et al. 2012) براساس توالىيابىهاى اين نواحى زنومى گَونهاى نهفته بسيارى درون گونههاى كميلكس اين جنس وجود دارند. هر جند يزوهشهاى مختلف منجر به معرفى گونهاى جديدى از داخل گونههاى مركب اين جنس شده است، اما شواهد نشان مىدهد، هنوز خطهاى تكاملى مجزايى درون جدايههاى برخى گَونهاى متعلق به اين جنس وجود دارند كه از نظر صفات مورفولوزيكى غير قابل تشخيص هستند (Amirmijani et al. 2015b) همكاران (Seifert et al. 2011) براى شناسايى گونههاى Cladosporium، علاوه بر داشتن تخصص و مطالعه خوب و دقيق خصوصيات ريختشناسى نمونهها، توالىيابى نواحى مختلف DNA را هم توصيه مى كنند. بررسى تنوع زيستى گونه مركب C. herbarum با استفاده از صفات ريختى، توليدمثل 
جنسى و آناليز فيلوزنتيكى توالى نواحى زنى اكتين، كالمودلين، عامل بسط دهنده ترجمه و يروتئين C. herbarum s. str. (Tel: هيستون نشان دادند، اين گونه در بركيرنده رينج گونه مختلف شامل C. bruhnei Linder (D. g, C. macrocarpum (D. macrocarpa) ‘Davidiella tassiana)

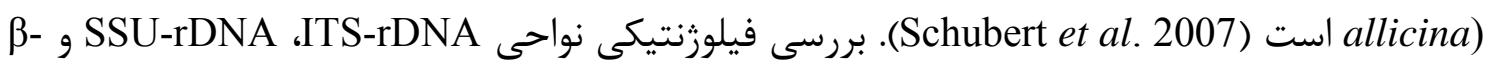
همراه با ويزگى هاى اكولوزيكى كونه مركب C. sphaerospemum منجر به شناسايى و معرفى هفت گونه جديد شد كه اين آرايههاى قابليت رشد در آب با درجه نمك بسيار زياد داشتند (Zalar et al. 2007). مطالعه بنش و همكاران (Bensch et al. 2010). در خصوص تنوع درون گونهاى (.). و اكولوزيكى كونه مركب C. cladosporioides با استفاده از توالى يابى سه زن act، ITS-rDNA و نشان داد اين گونه در بر گيرنده بالغ بر r tef منطقه جغرافيايى خاصى هستند. همجنين بررسى جند زنى با استفاده از نواحى act، ITS-rDNA و Bensch et al. ( توسط بنش و همكاران منجر به معرفى 19 كونه جديد در اين جنس شده استى .(2018

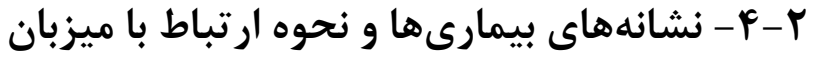

برخى كونههاى اين قارجها مانند C. neriicola S.A. Khan \& M.A. Kamal (روى خرزهره) و C. echinulatum (Berk.) G.A. de Vries مىشوند (Amirmijani et al. 2015a). تاكنون حدود • V ₹ونه بيمارگر زياهان از اين جنس معرفى و توصيف شدهاند، كه معمولاً از اختصاصيت ميزبانى برخوردار هستند. گونههاى كندرو آن مانند C. cladosporioides s.1. و به طور فراوان روى ساقه و برىهاى مرده يا يزمرده ب. .C. herbarum s.l. حَياهان علفى و جوبى رشد مى كنند و به عنوان عوامل آلوده كننده ثانويه روى زخمهاى نكروزه برگها كه توسط ساير قارجها ايجاد شده است، عمل مى كنند. گَونه C. uredinicola فرانكل مرحله تليومى و يورودينيومى زنخها، سفيدكهاى كركى وسفيدكهاى يودرى است و گونه C. phyllactinicola قادر به يارازيته كردن Phyllactinia guttata است. همجنين C. aphidis قادر به آلوده كردن آفات مهرم كَياهى خصوصاً شتهها و مغَسهاى سفيد بوده و از جنبه مبارزه زيستى با آنها اهميت ييدا مى كنند.

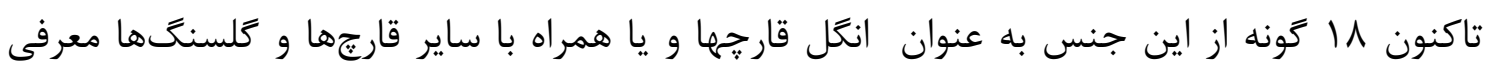

شده است (Bensch et al. 2012). 

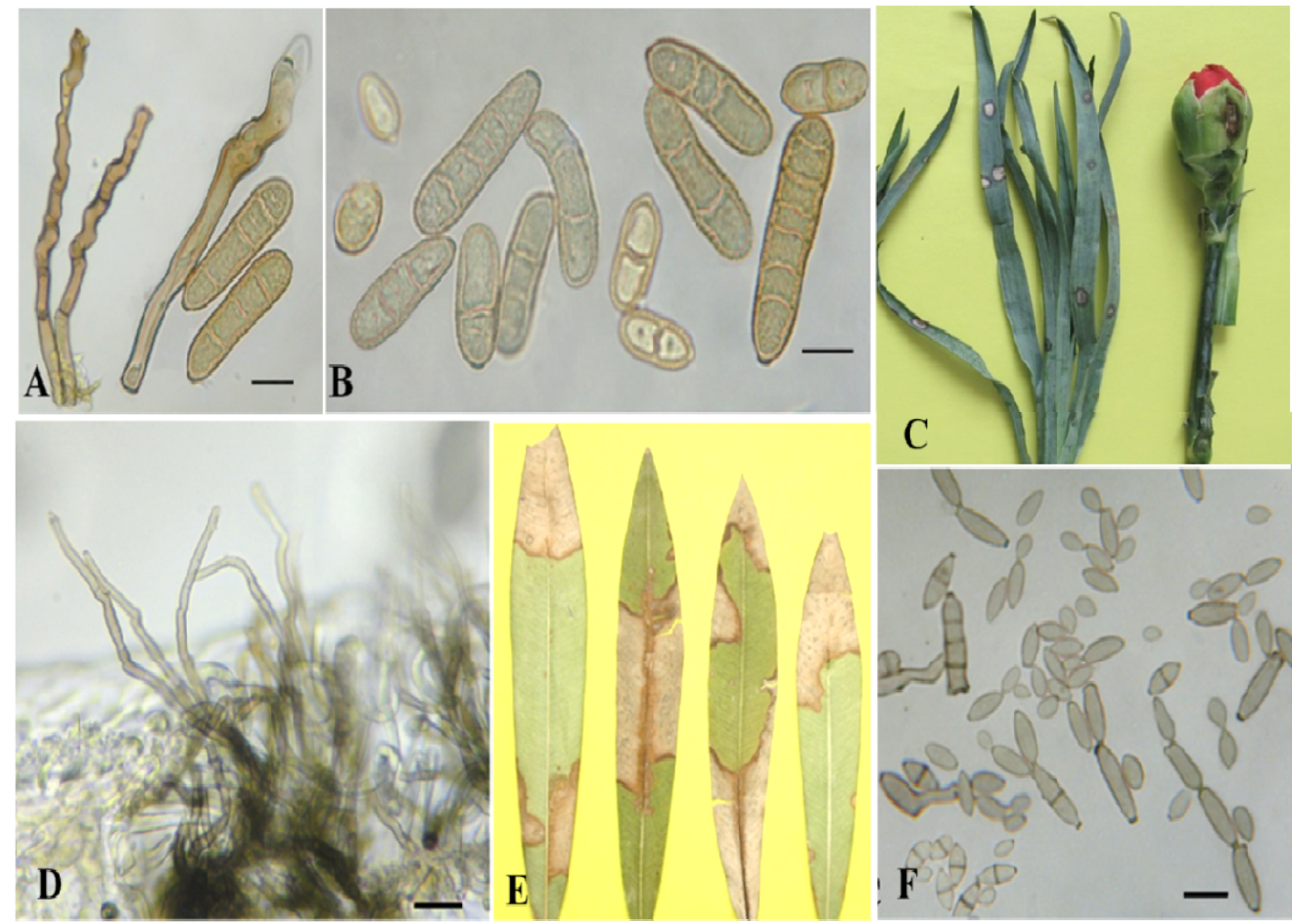

شكل r. A-C: كنيديومبر، كنيديوم و لكه برگى ناشى Cladosporium echinulatum روى ميخك (D-F (Dianthus sp.) كنيديومهاى Cladosporium neriicola (اصلى).

Figure 2. A-C: Conidiophores, Conidia and leaf spot of Cladosporium echinulatum on Dianthus sp., D-F: Conidiophores, leaf spot on Nerium oleander and conidia of Cladosporium neriicola

\section{نتيجهلَيرى}

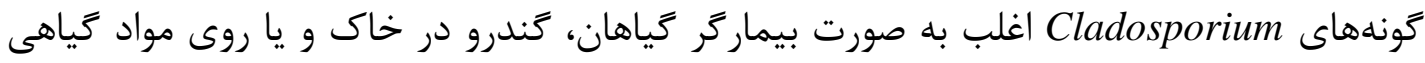
خشك، يا فراانكل ساير قارجها زندگى مى كنند. مطالعه آرايه بنديكى گذشته اين جنس در ايران تنها يزوهشهاى : يراكندهاى كه اغلب محدود به گزارشهاى قديمى از اين قارج روى برخى گياهان است را شامل مىشود. بدون شك اين اطلاعات ناقص بوده و بيانگر ميزان گسترش وسيع گَونهاى اين قارج در ايران نيست. همجنين به دليل عدم دسترسى به اغلب نمونهاى قديمى جمعآورى شده در ايران، امكان بازنكرى و تجديد نظر نام گونهها با توجه به تغييرات ايجاد شده در آرايهبندى نوين اين جنس وجود ندارد. بنابراين جمعآورى و شناسايى گونهاى اين جنس بر اساس خصوصيات ريختى و دادهاى مبتنى بر DNA در ايران، براى يافتن راهى براى شناخت دقيق و سريع گونههاى كمتر شناخته شده و يا معرفى گونهاى جديد اين قارجهاى بيمار زر گياهان ييشنهاد مىشود. 


\section{References}

1. Abdel-Baky N.F. and Abdel-Salam A.H. 2003. Natural incidence of Cladosporium spp. as a bio-control agent against whiteflies and aphids in Egypt. Journal of Applied Entomology 127:228-235.

2. Amirmijani A. R., Khodaparast S. A. and Zare R. 2013. Preliminary study of the genus Cladosporium in the North of Iran. $1^{\text {th }}$ Iranian Mycological Congress, Rasht, Iran. P.20.

3. Amirmijani A.R., Khodaparast S.A. and Zare R. 2014. Contribution to the identification of Cladosporium species in the North of Iran. Rostaniha 15:133145.

4. Amirmijani A. R., Khodaparast S. A. and Zare R. 2015a. Additions to the knowledge of the genus Cladosporium in Iran. Mycologia Iranica 2:11-21.

5. Amirmijani A. R., Khodaparast S. A., Zare R. and Javan-Nikkhah M. 2015 b. Phylogenetic analysis of some Iranian isolates of the genus Cladosporium. Asian Mycological Congress. 7-10 October., Goa University, Goa, India. P.104.

6. Bensch K., Braun U., Groenewald J. Z. and Crous P. W. 2012. The genus Cladosporium. Studies in Mycology 72:1-401.

7. Bensch K., Groenewald J. Z., Dijksterhuis J., Starink-Willemse M., Andersen B., Summerell B. A., Shin H. D., Dugan F.M., Schroers H. J., Braun U. and Crous P.W. 2010. Species and ecological diversity within the Cladosporium cladosporioides complex (Davidiellaceae, Capnodiales). Studies in Mycology 67:1-94.

8. Bensch K., Groenewald J. Z., Meijer M., Dijksterhuis J., Jurjevi Z., Andersen B., Houbraken J., Crous P.W. and Samson R.A. 2018. Cladosporium species in indoor environments. Studies in Mycology 89:177-301.

9. Crous P. W., Braun U., Schubert K. and Groenewald J. Z. 2007. Delimiting Cladosporium from morphologically similar genera. Studies in Mycology 58:3356.

10. David J. C. 1997. A contribution to the systematics of Cladosporium. Revision of the fungi previously referred to Heterosporium. Mycological Papers 172:1-157.

11. Ellis M. B. 1971. Dematiaceous Hyphomycetes. Commonwealth Mycological Institute, Kew, Surrey. 608p.

12. Heuchert B., Braun U. and Schubert K. 2005. Morphotaxonomic revision of fungicolous Cladosporium species (Hyphomycetes). Schlechtendalia 13:1-78.

13. Hoog G. S., Guarro J., Gené J. and Figueras M. J. 2000. Atlas of Clinical Fungi, 2nd ed. Centraalbureau voor Schimmelcultures, Utrecht. The Netherlands.

14. Khodaparast S. A., Zahedi M., Amirmijani A. R. and salami M. 2012. New reports on mitosporic fungi from the Caspian Sea area (N Iran). Rostaniha 13:3137.

15. Schubert K. 2005. Morphotaxonomic revision of foliicolous Cladosporium species (Hyphomycetes). Ph.D. thesis, Martin-Luther-University, Halle. 
16. Schubert K., Groenewald J. Z., Braun U., Dijksterhuis J., Starink M., Hill C. F., Zalar P., Hoog G. S. and Crous P. W. 2007. Biodiversity in the Cladosporium herbarum complex (Davidiellaceae, Capnodiales), with standardization of methods for Cladosporium taxonomy and diagnostics. Studies in Mycology 58:105-156.

17. Seifert K., Morgan-Jones G., Gams W. and Kendrick B. 2011. The Genera of Hyphomycetes. CBS Biodiversity Series 9. Utrecht. The Netherlands.

18. Zalar P., Hoog G. S. Schroers H. J., Crous P. W., Groenewald J. Z. and GundeCimerman N. 2007. Phylogeny and ecology of the ubiquitous saprobe Cladosporium sphaerospermum, with descriptions of seven new species from hypersaline environments. Studies in Mycology 58:157-18 